\title{
Trade, Democracy, and the Size of the Public Sector: The Political Underpinnings of Openness
}

\author{
Alícia Adserà and Carles Boix
}

To account for the strong and positive correlation found between trade openness and the size of the public sector, scholars have developed theoretical explanations in which politics have remained conspicuously absent in two ways. ${ }^{1}$ First, why some economies are more open than others has been (implicitly) attributed to parameters exogenous to the political decisions of domestic actors. Second, the presence of a sizable public sector has been merely thought of as an automatic, and in some cases a functional, requirement of a free trade regime. This mechanical link has come in two forms. In Rodrik shows that higher levels of trade integration (coupled with high sectoral concentration in the economy) increase the risks associated with the international business cycle and call for publicly-financed compensatory programs in favor of the exposed sectors. ${ }^{2}$ Public expenditure, set by a state purely conceived as a social planner, stabilizes aggregate income and delivers social peace and political stability. In Aukrust argues that the tradeable sector, modeled as an international-price-taker, employs public spending to buy the acquiescence of the non-tradeable sector to low wage increases, therefore ensuring the overall competitiveness (and survival) of the national economy. ${ }^{3}$

Earlier versions of this paper were presented at the German-American Academic Council Summer Institute at Stanford University, the Department of Government and Foreign Affairs of the University of Virginia, the Department of Political Science at Ohio State University, the Department of Economics at Ohio State University, the 1999 Annual Meeting of the Midwest Political Science Association, the 1999 Midwest Economics Association Meeting, the Workshop on Politics, Nations, and States in Comparative Perspective at the University of Chicago, and the 2000 Annual Meeting of the American Political Science Association. We thank the participants for their comments, particularly Greg Caldeira, Dan Levin, Peter Gourevitch, Lloyd Gruber, Michael Hiscox, Dean Lacy, Peter Lange, Jim Peck, Ron Rogowski, and Herman Schwartz.

1. See Cameron 1978; Katzenstein 1985; and Rodrik 1998.

2. Rodrik 1998.

3. Aukrust 1977. Katzenstein includes both arguments. Katzenstein 1985. In Cameron the level of public spending is a function of the political power of unions, which in turn derives from the openness of the economy. Cameron 1978. 
In this article we model the choice of the level of trade openness and the determination of the size of the public sector as two political decisions that are simultaneously taken by political agents. In this sense, we simply build upon the insights of the literature on both the domestic determinants of trade policy and the origins of the welfare state, which respectively insist that the extent of trade openness and the tax level derive from the particular distribution of domestic interests. $^{4}$

Once the choice of tariffs and taxes is modeled as a simultaneous political game, any mechanical correlation between trade openness and domestic compensation breaks down. Domestic compensation emerges as just one possible strategy to build a free trade coalition. Its use to secure low tariffs is neither necessary (free trade may be achieved without increasing public spending) nor sufficient (a protectionist solution can still be imposed in spite of a compensatory promise from the free trade gainers to the losers from free trade). More precisely, the following set of alternative political-economic equilibria constitute equally possible outcomes across the universe of nations:

1. To insulate domestic actors from internationally-induced changes in relative prices, national policymakers may choose to close the domestic economy. Once domestic actors are relatively isolated from external competition and the variability of the world business cycle, there are no incentives to resort to higher levels of public expenditure to compensate voters for (temporary or permanent) employment losses. ${ }^{5}$ As a result, economic insulation should be expected, ceteris paribus, to depress the level of public expenditure. ${ }^{6}$

2. A second policy outcome takes place whenever the sectors that gain from trade set up public programs to compensate trade losers to get the latter's political support for an open economy. Accordingly, as we stress in this article, the expansion of the public sector is not a mere derivation of trade openness-as assumed in most of the current literature-but a truly political pre-condition needed to secure the liberalization of the economy.

3. Since the construction of a political coalition to secure low tariffs may require high taxes, policymakers may decide to keep the economy open while minimizing public expenditure. Since this solution may have substantial redistributive consequences, such as lower levels of welfare protection and increases in income inequality during economic downturns, this laissez-faire strategy can only be implemented after excluding, in a systematic manner, all trade losers. In other words, as we shall show, the combination of an open

4. On trade policy, see Alt et al. 1996; Gourevitch 1986; and Frieden and Rogowski 1996. On the welfare state, see Meltzer and Richards 1981; and Esping-Andersen 1990.

5. As a matter of fact, once the economy is closed, aggregate demand management becomes an effective strategy to minimize the occurrence of recessions. Policymakers can then engage in countercyclical policies to smooth the business cycle. For evidence showing that closed economies and inflation are strongly and positively correlated, see Romer 1993; and Campillo and Miron 1997.

6. For a first attempt to point to autarky as a substitute for domestic compensation under a free trade regime, see Bates, Brock, and Tiefenthaler 1991. 
economy and no public compensation takes place, in most cases, under an authoritarian political regime.

We explore these alternative combinations of trade policy, fiscal strategy, and political regimes through a formal model, a test on a sample of approximately sixty-five nations from 1950 to 1990, and historical evidence spanning a longer period of time. The first part of the article examines the choices policymakers make on both the degree of openness and the size of the public sector. The model is based on a set of actors with heterogeneous preferences in both policy dimensions (trade and public sector) due to their exposure to trade and the variability of their potential trade gains. Given a rather generic distribution of interests, we show, first, that politicians engaged in democratic competition may develop two alternative economic strategies (to win elections): they either support a protectionist regime or defend a program that combines free trade and domestic compensation. The model then goes on to allow politicians to choose, given the available set of policy alternatives, the political regime they would impose-either a democracy or an authoritarian regime. This section shows under what conditions those sectors interested in free trade have an incentive to impose an authoritarian regime to secure a liberal trade regime without domestic compensation. In the second section, we test the model on a sample that includes all the countries for which comparable data on public revenue (current receipts) of the general government were available from 1950 to 1990 . The statistical analysis is followed by the examination of a set of key historical cases from the nineteenth and twentieth centuries to bring out the dynamics that underlie the choice of tariffs and taxes under different political regimes. In the last section, we draw our conclusions.

\section{Theory: Trade, Taxes, and Political Regime}

\section{The Distribution of Interests}

As shown in the literature on the political determinants of trade policy, different economic agents have different material interests, and therefore distinct policy preferences, depending on their position in the international economy. The attitudes of economic actors toward trade and trade policy may be determined by two factors: first, the potential benefits to be derived from trade, which go from net gains to net losses; and second, the variability of the returns derived from trade, that is, the probability that trade will lead to gains or losses given the nature of the actor's assets. This second component simply captures the degree of uncertainty that actors face over the future realization of some gains (or losses) in trade and their incapacity, once they have embraced a free trade regime, to use standard countercyclical policies to combat the volatility of the world business cycle.

In its simplest form, consider an economy in which there are three types of individuals with distinct trade interests, $C, P$, and $O$. Each individual can be thought of as a representative agent of an economic factor, a productive sector, or a set of homogeneous firms. This model, therefore, takes the definition of each actor's 
position in the international economy and its interests as given-it does not adjudicate between factor-based or sector-based models of international political economy and should be applicable to any of them. ${ }^{7} C$, or the pro-closed-economy agent, only stands to lose from opening the economy-his returns decline, in a linear fashion, as tariffs are reduced. In a Heckscher-Ohlin model, for example, $C$ would be an owner of capital in a capital-scarce economy. Formally, the utility of $C$ can be represented as:

$$
U_{c}=(1-\lambda) C_{c}+\lambda C_{o}
$$

where $\lambda$ is the extent to which the economy is open in an interval $[0,1], C_{c}$ is the return to $C$ when the economy is closed, $C_{o}$ is the return to $C$ when the economy is open, and $C_{c}>C_{o}$.

$O$, instead, consists of the agent who always gains from free trade- his returns always rise as the economy becomes more open. Again, within the framework of a Heckscher-Ohlin model, $O$ would be a landowner in a land-abundant country. The utility of $O$ is defined by:

$$
U_{o}=(1-\lambda) O_{c}+\lambda O_{o}
$$

where $O_{c}$ is the return to $O$ when the economy is closed, $O_{o}$ is the return to $O$ when the economy is open, and $O_{c}<O_{o}$.

Finally, $P$ represents an agent whose gains from trade are always subject to considerable variation over time. If the international business cycle (or the specific demand for $P$ 's products) is booming, $P$ benefits from a free trade regime. If the international business cycle is in recession, free trade harms $P$ substantially. Accordingly, $P$ ranks her preferences in the following fashion: an open economy under a good business cycle is preferred to a closed economy regime, yet this latter regime is certainly more attractive than a laissez-faire regime when the economic cycle goes through a recession. ${ }^{8}$ The expected utility of $P$ can be represented as:

7. For a discussion of the definition of each actor's interests, see Frieden and Rogowski; and Alt et al. 1996.

8. The presence of $P$ captures in part the empirical fact that trade is correlated to variations in the business cycle across countries. Using the Summers-Heston (1988) database (that includes 147 nations for the period 1950-90 and 4,546 observations), the volatility of the business cycle (calculated as the standard deviation of changes in the growth rate in 5-year periods) can be shown to increase with trade openness. More specifically, for each logged unit of trade openness, the volatility of the business cycle goes up by 0.60 (which is statistically significant at the 1 percent level). The result is robust to the introduction of control variables such as per capita income, economic structure, and weight of fuel and primary exports. 


$$
E U_{p}=(1-\lambda) P_{c}+\lambda\left[\pi P_{g}+(1-\lambda) P_{b}\right]
$$

where $P_{c}$ is the return to $P$ if the economy is closed; $P_{g}$ is the return to $P$ if the economy is open and the international business cycle is booming; $P_{b}$ is the return to $P$ if the economy is open and the world business cycle is in recession; the ranking of returns is $P_{g}>P_{c}>P_{b}$; and $\pi$ is the probability that the world business cycle will be expansive.

For any $P$ the expected return under an open economy is smaller than under a closed economy:

$$
\pi P_{g}+(1-\lambda) P_{b}<P_{c}
$$

For sake of simplicity, we have assumed that $P$ is risk-neutral so that her expected utility equals her expected return. If we had characterized $P$ as risk-averse, $P$ 's demands for compensation from $O$ to acquiesce to free trade policies would have become more intense. ${ }^{9}$ There would have been a set of points for which, although $P$ 's expected returns would have been higher under an open economy (and thus condition [3'] would not hold), $P$ would have still preferred a closed economy to minimize risks unless a compensation policy would have been promised by $O$.

The position of these economic actors affects, in turn, their attitudes toward trade policy. $C$ and $O$ espouse completely different policy positions. Whereas $C$ favors autarky, $O$ is in favor of full free trade. In turn, $P$ 's position is conditional on the evolution of the world business cycle and, more interestingly, on the introduction of some mechanism that could smooth the variability of the business cycle. If $P$ can secure a future compensation package (via public transfers) to make up for any losses in recession periods, its willingness to support free trade policies will increase. Conversely, if the public sector has devised no compensatory mechanisms, $P$ 's support for free trade will decline. The position of each agent is represented in Figure 1. $C$ and $O$ have their bliss points at the extreme opposites of the trade policy dimension (horizontal axis). Their support for either protectionism or free trade is independent of the level of compensation they may get. ${ }^{10}$ Their indifference curves (with a loss of utility higher along the horizontal than on the vertical axis for $O$ ) have been drawn to stress that trade policy matters more than the level of compensation. $P$ 's support for free trade cannot be separated from his demand for a compensatory mechanism. Thus two different equilibria may ensue. A coalition between $C$ and $P$ would hinge upon high tariffs and no compensation mechanisms. Instead, in

9. With risk aversion, $P$ 's expected utility function is:

$$
E U_{p}=\pi U\left[(1-\lambda) P_{c}+\lambda P_{g}\right]+(1-\pi) U\left[(1-\lambda) P_{c}+\lambda P_{b}\right]
$$

where $U^{\prime}>0$ and $U^{\prime \prime}<0$.

10. It could be argued, however, that, other things equal, $O$ may have a higher interest in getting some compensation given its higher exposure to trade-that is, that $O$ may also be affected by the variability of the terms of trade. This possibility is not modeled here for the sake of simplicity. 


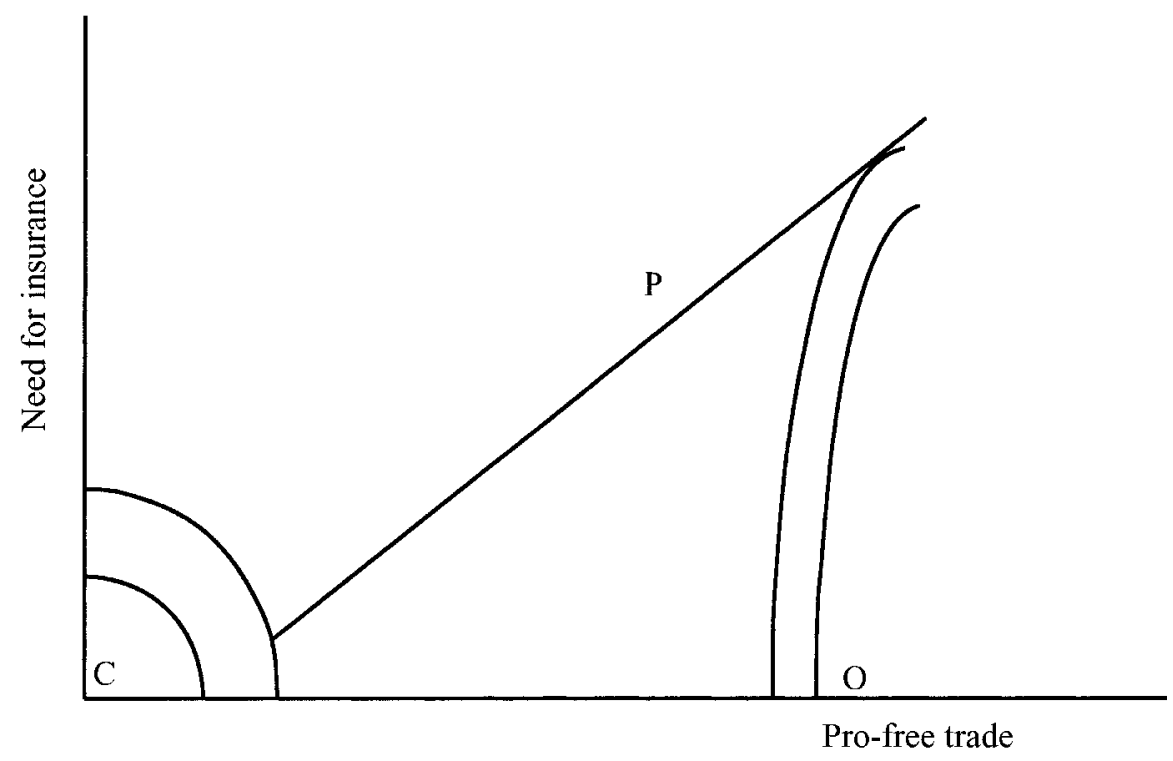

FIGURE 1. Support for free trade in a two-dimensional policy space

exchange for public compensation, $P$ could be equally willing to support $O$ 's free trade policy preferences.

\section{The Choice of Trade and Fiscal Policies under a Democratic}

\section{Arrangement}

Consider now how both trade and fiscal policies are jointly determined in that economy. Political decisions take place through two procedures that may occur sequentially or simultaneously. First, policies are or may be chosen through a voting or democratic mechanism. Second, (some) actors, unsatisfied with the actual or anticipated outcome in a democratic setting, may contest the voting procedure and establish an authoritarian regime that, by excluding any opposition, secures their most preferred policy outcome. (See the appendix for the formal derivation of the equilibria.)

Let us consider first what happens in a democratic regime. (In this subsection we fix the constitutional regime. In the next subsection, we explore the policy outcomes when we allow actors to contest the regime itself.) At national elections held periodically, $C, O$, and $P$ may choose among two parties. A protectionist party, party $\Sigma$, which draws its financial and electoral support from $C$ (the pro-closed economy sector), favors high tariffs. The pro-free trade party, party $\Omega$, which receives its support from pro-free trade voters, $O$, defends a free trade regime. Neither $C$ nor $O$ 
controls a majority of the vote. ${ }^{11}$ Accordingly, $P$, who is the median voter (in the trade-policy dimension), holds the balance between the two forces. ${ }^{12}$

The sequence of the game between the economic actors $(C, O, P)$ and the two contending parties $(\Sigma, \Omega)$ is as follows. Both parties, $\Sigma$ and $\Omega$, choose their policy programs before elections. Once they have committed to a certain policy strategy, they cannot credibly alter their initial promises. ${ }^{13}$ The choice of their electoral promises is made under conditions of uncertainty about how the international business cycle will be after the election takes place. Voters then vote for partiesdepending on their programs and their forecast about the future. After the election, the world business cycle expands with a probability $\pi$ and is in recession with a probability $1-\pi$. A recession affects all the $P$ voters at the same time. ${ }^{14}$

If neither $C$ nor $O$ has a majority of the votes, party 3 has two possible choices. On the one hand, it may just promise low (or no) tariffs. On the other hand, it may promise low (or no) tariffs jointly with the introduction of a publicly-funded scheme to compensate the $P$ sector in case a world depression occurs. In turn, $\Sigma$ always promises an autarkic regime. $\Sigma$ does not develop any compensatory mechanism related to trade since, under a closed economy, there is no volatility involved. Still, the protectionist party may promise a transfer to match the offer of the free trade party.

To determine the strategy of parties and the final result of elections, let us examine first how voters vote. For the free trade party $\Omega$ to win, $O$ and $P$ will have to vote for it. Consider first the vote of the pivotal voters, $P$. At election day, $P$ voters do not know the evolution of the business cycle. Their expected returns will be what they would gain in an open economy (and these gains are affected by the variation in the economic cycle) or what they would gain in a closed economy. $P$ voters will vote for the free trade party, $\Omega$, if the returns under an open economy plus the compensation package this party promises are larger than the returns to be obtained in a closed economy jointly with any transfers established by the protectionist party $\Sigma$.

Which strategy will $\Omega$ pick? Given that the ex ante expected gains from openness are lower for $P$ than the certain gains from autarky (as stated in condition [3']), $\Omega$ must always commit to a certain compensation package, $\alpha_{\mathrm{o}}$, to attract $P$. Such a

11. The lack of a majority of $C \mathrm{~s}$ or $O \mathrm{~s}$ (and the corresponding pivotal role of $P$ ) is a plausible way of capturing the possibility of volatility, which we have found to be inherently related to trade across countries. Again, $C(O)$ always benefits from protectionism (free trade). P's return is conditional on the business cycle.

12. A similar situation arises if, instead of an electoral arena, we think of a parliament in which the three agents have attained representation in a proportion equal to their electoral strength. The party representing $P$ would be the median parliamentarian.

13. That is, since voters take into account the reputation of the party, parties cannot modify their party platforms once in government to tailor them to cyclical economic conditions.

14. Altering the sequence of the game (with nature-the business cycle-occurring after parties commit but before voters vote) and the impact of the recession on $P$ (with every $P$ having an independent probability $1-\pi$ of suffering a recession instead of all $P$ s being affected by it at the same time), does not substantially change our results. 
package has to meet two criteria. First, the compensation program $\alpha_{\mathrm{o}}$ will have to outmatch any spending package $\alpha_{c}$ promised by the protectionist party, $\Sigma$. (Notice that $C$ 's cost of this compensation package $\alpha_{c}$ can never be higher than the difference between what each $C$ gains under a protectionist regime and what he gains under free trade. If it were, $C$ voters would not vote for the protectionist party.) Second, the compensation package $\alpha_{\mathrm{o}}$ promised by the free traders should not alienate the $O$ voters - otherwise they would not vote for the free trade party. (In a way symmetrical to what happens to the protectionist parties and their core supporters, $O$ voters will only vote for $\Omega$ up until the point in which the gains of an open economy are larger than the gains of a closed economy even allowing for the compensation they may have to pay to each $P$ voter.) Finally, it is important to stress that the compensation package promised by the free trade party will always be larger than the spending package offered by the protectionist party, since the former has to overcome the lower expected return of the pivotal voter in an open economy relative to a closed economy. In short, free trade (resulting from democratic elections) boosts the public sector more than protectionism.

Several implications about what determines the winner of the electoral stage can be derived from our discussion. First, the size of each group matters. As the number of $O$ voters increases, the free trade party is more likely to win an election. ${ }^{15}$ Second, the returns to each factor or sector also matter. As the gains from free trade increase, $O$ will have more resources to pay off $P$ voters, and the victory of $\Omega$ becomes almost certain. ${ }^{16}$ Finally, as the volatility of the business cycle diminishes, the cost to lure $P$ voters will decline, and a free trade regime will become easier to establish.

\section{Trade, Fiscal Policy, and the Choice of Political Regime}

In a democratic setting, unless $O$ commands a majority of votes, securing a free trade regime has a political and financial cost. To have an open economy, $O$ has to compensate $P$. If the cost involved in ensuring that $P$ votes for a pro-free trade party is too high, $O$ will choose not to promise any compensation. But, again, this decision will cost $\Omega$ the election and will lead to the passage of protectionist policies.

15. In the presentation of the model we have assumed full participation of voters. Naturally, if turnout declines (asymmetrically) across sectors, the policy regime may vary. Similarly, differential rates of participation can be equated to different levels of lobbying effort across sectors (resulting in different proportions of votes).

16. Notice that these two implications can be combined to predict the likelihood and traits of the policy outcome in the following way. Assume a factor-based model of trade preferences. In laborabundant economies, the majority of the population (at least in a setting as described by Mayer) will lean toward free trade and, as a result, compensation policies may be small in size (Mayer 1984). By contrast, in labor-scarce economies, where the majority loses from trade, compensation packages will tend to be substantial. The goal of this article is to test how trade and political regime affect fiscal policy. Still, we tentatively consider the impact of the abundance/scarcity of labor in a set of regressions reported below in note 30 . We are grateful to Michael Hiscox for having drawn our attention to this possibility. 
A different political alternative is, however, still available to $O$. Instead of accepting an electoral defeat, $O$ may decide to impose an authoritarian regime to secure free trade policies. Naturally, a similar option is available to $C$. If $\Sigma$ cannot win the election, it may still resort to a dictatorship to secure a protectionist regime. (A caveat is in order. In what follows, we do not claim that the level of conflict over trade policy solely determines the choice of political regime. There is already an abundant literature on those factors - mainly economic modernization - that affect the likelihood of a democratic outcome. ${ }^{17}$ Accordingly, we simply outline a theory as to why, in the margin, with all the other relevant factors constant, trade conflict may lead to either a democracy or an authoritarian regime, and with what policy consequences.)

Under what conditions will the two parties resort to an authoritarian solution? Suppose that there is a cost to impose a dictatorship $-w$ or the cost of repressing each member of those economic sectors that are permanently excluded from government. $O$ will impose a dictatorship if three conditions are met:

1. The final burden to each $O$ of imposing a dictatorship does not exceed the difference between the gains under an open economy and the gains under a closed economy. If they did, a dictatorship would absorb all the economic advantages of establishing it, and naturally, $O$ would have no logical incentive to pursue the authoritarian strategy.

2. The resources of $O$ are larger than the resources $C$ has to establish a dictatorship - that is, when a pro-free trade dictatorship cannot be contested by the protectionist sector. Otherwise, $C$ is able to impose an uncontested dictatorship.

3. Finally, whenever $O$ could compensate $P, O$ will impose a tyranny if this solution is cheaper than paying for a compensation package. If compensating $P$ were not feasible for $O, O$ would establish a dictatorship whenever conditions (1) and (2) occurred.

Solving analytically these three conditions, it is apparent that the outcome will hinge on the number of individuals in each sector, the difference in the gains of each sector under each policy regime (open or closed), and the variability of the cycle in the following way. ${ }^{18}$

Consider, to start with, a scenario where $O$ and $C$ experience symmetrical gains (losses) as a result of trade policy. That is, the losses that one sector (for example, $O$ ) experiences when policy is shifted (for example, going from free trade to protectionism) are similar to the gains the other sector ( $C$ in this case) enjoys. In this case, a democratic outcome is unlikely: a dictatorship is generally cheaper than the compensatory policies that must be enacted after an election. The capacity of each sector to impose a dictatorship is balanced. Who prevails simply depends on their respective numbers. As $C$ becomes larger in numerical terms (relative to $O$ ), a

17. See Lipset 1959; Rueschemeyer, Stephens, and Stephens 1992; Przeworski and Limongi 1997; and Boix and Garicano 2001.

18. The solutions are formally shown at the end of the appendix. 
protectionist outcome will be established. Conversely, as $O$ becomes larger, a free trade dictatorship will be imposed (with the public sector remaining small). The variability of $P$ 's gains has no appreciable impact on $O$ 's strategy: even if the variability of $P$ 's gains is low (and the compensation package to lure $P$ is small), democracy is not generally pursued by the free trade sector. The protectionist sector can easily outmatch any compensation since it has similar resources at stake.

Results change when $O$ stands to gain relatively more from openness than $C$ from autarky. $O$ 's capacity to impose an uncontested dictatorship increases steadily (since it can amass resources rapidly). But, interestingly, the gains of trade make democracy (with compensation) cheaper at a faster rate. Thus democracy and free trade start becoming the dominant strategy for $O$, even in those circumstances in which a dictatorship also could be imposed by $O$. This effect, though weaker, holds even when $P$ 's compensation package must be relatively high.

\section{Empirical Evidence}

To overcome the absence of a truly political explanation for the simultaneous occurrence of openness and a sizable public sector in a substantial number of countries, in the previous section we modeled the joint selection of trade policy, the size of the state, and political regime for any country. We showed that three distinct political-economic equilibria may occur. First, in nations that hardly trade, the public sector should be smaller, other things being equal. Again, the reason is straightforward: in a closed economy policymakers have no incentive to expand the public sector to compensate the losing sectors of the economy. Second, in fully democratic polities, a free trade regime leads to the expansion of the public sector to compensate losers from international recessions or shocks. Finally, since open economies can only shirk from committing resources to losing sectors of the economy by excluding them from the political decision-making process, free trade will not imply a bigger government under authoritarian regimes.

\section{Sample}

To examine the strength of our theory, we use a sample that includes all the countries for which comparable data on public revenue (current receipts) of the general government are available from 1950 to 1990 . We used two sources for our sample: the United Nations (UN) National Accounts and the Organization for Economic Cooperation and Development (OECD) National Accounts. ${ }^{19}$ The data start in 1950 and cover approximately 65 countries (22 are OECD members), with some variation in the years covered, providing about 2,000 data points. 


\section{Dependent Variable}

The dependent variable "Size of Government" is measured through current receipts of the general government as a percent of gross domestic product (GDP) ${ }^{20}$ Current receipts have been chosen over public expenditure to maximize the sample under analysis. Current disbursements of general government as a percentage of GDP (taken from the UN National Accounts) include much fewer countries (and, by excluding capital spending, underreport the size of government). Although two other alternative databases offer larger samples for parts of public expenditure, they are also unsuitable for our analysis. Although the Penn World Tables report the share of government consumption of more than a hundred countries, government consumption, which is the measure recently employed to test the effect of trade on public spending, represents a fraction of all government spending and is biased in favor of developing countries. ${ }^{21}$ The World Bank reports levels of government spending for, at most, around eighty countries. Still, these data (as well as the International Monetary Fund data) report spending only at the central government level and lead to extremely biased values for federal countries (which tend to be less open on average).

\section{Model and Results}

To determine the impact of trade and the interaction of trade and political regime on the size of government, we first estimate the following model on a time-series cross-sectional panel of nations in Table 1:

Size of Government $t_{t}=\alpha+\alpha_{1}$ Economy $_{t}+\alpha_{2}$ Trade $_{t}+\alpha_{3}$ Political Institutions $_{\mathrm{t}}+\alpha_{4}$ Trade $_{\mathrm{t}} *$ Political Institutions $\mathrm{t}_{\mathrm{t}}+\varepsilon_{\mathrm{t}}$

We estimate the pooled cross-sectional time-series model through ordinary least squares, adjusting the standard errors for unequal variation within panels and correcting for autocorrelation. ${ }^{22}$ Table 2 checks for the robustness of the results of Table 1 in several ways. It first introduces the lagged value of the dependent variable and then re-estimates the model using both fixed-effects and random-effects procedures.

In Table 3 we estimate the same model using change rather than level of the parameters, that is:

Change in Size of Government $=\alpha+\alpha_{1}$ Size of Government $t_{t-1}+\alpha_{2}$ Change in Economy $+\alpha_{3}$ Change in Trade $+\alpha_{4}$ Change in Political Institutions $+\alpha_{5}$ Change in (Trade* Political Institutions) $+\mathrm{G}_{\mathrm{t}}$

20. According to the UN/SNA, the current receipts include operating surplus, property and entrepreneurial income, taxes, fees and contributions, and other current transfers.

21. Rodrik 1998.

22. Beck and Katz 1995. 
TABLE 1. The size of governments across the world: trade, development, and political regimes

Public revenue as percent of GDP, 1950-1990

\section{Independent variables}

(1)

(2)

(3)

(4)

(5)

(6)

\section{Constant}

Per capita income $(\log )^{\mathrm{a}}$

Trade openness (log of sum of exports and imports over GDP) ${ }^{\mathrm{b}}$

Democratic institutions ${ }^{c}$

Democratic institutions $\times$ Trade openness

Log area (thousand $\mathrm{km}^{2}$ )

Distance

Subsaharan Africa

\section{East Asia}

Latin America

OECD countries

Weighted level of tariffs on intermediate inputs and capital goods

Export concentration

Export concentration $\times$ Trade openness

Export concentration $\times$ Trade openness $\times$ Democratic institutions

Volatility in terms of trade

Volatility $\times$ Trade openness

Volatility $\times$ Trade openness $x$ Democratic institutions

Model Chi-square

$\mathrm{P}>$ Chi-square

Number of observations

$\begin{array}{cc}-40.26^{* * *} & -37.39^{* * *} \\ (5.54) & (4.99) \\ 6.20^{* * *} & 6.15^{* * *} \\ (0.51) & (0.51) \\ 3.95^{* * *} & 3.30^{* * *} \\ (0.54) & (0.79) \\ & \\ 2.69 * * * & -2.35^{\wedge} \\ (0.68) & (3.46) \\ & 1.33^{\wedge} \\ & (0.96)\end{array}$

$-38.56 * * *$
$(6.40)$

$-37.47 * * *$

$-39.58 * * *$

$\begin{array}{lll}37.47 * & (6.46) \quad(9.31) & (6.83)\end{array}$

$\begin{array}{llll}(0.71) & (0.71) & (0.86) & (0.73)\end{array}$

$2.18 * * * \quad 2.13 * * * \quad-1.24 \quad 2.37$ *

$\begin{array}{llll}(0.86) & (0.86) & (1.42)\end{array}$

$\begin{array}{llll}-4.87 & -4.69 & -8.87 * & 2.43\end{array}$

$\begin{array}{llll}(3.41) & (3.40) \quad(4.81) & (4.94)\end{array}$

$\begin{array}{llll}2.19 * * & 2.18 * * & 3.22 * * * & -0.14\end{array}$

$\begin{array}{llll}(0.94) & (0.94) \quad(1.31) & (1.37)\end{array}$

$\begin{array}{llll}0.96 * * * & 1.05 * * * & 0.91 * * & 0.00\end{array}$

$\begin{array}{llll}(0.30) & (0.32) & (0.39) & (0.38)\end{array}$

$\begin{array}{llll}-0.71 * * & -0.70 * * & -0.84 * * & -0.68 * *\end{array}$

$\begin{array}{llll}(0.28) & (0.28) & (0.40) & (0.32)\end{array}$

$\begin{array}{llll}2.44 & 2.30 & -1.17 & 4.21\end{array}$

(2.48) (2.45) (3.11)

$\begin{array}{llll}-1.52 & -1.33 & -6.12 * * & -1.05\end{array}$

$\begin{array}{llll}(2.13) & (2.10) & (2.81) & (2.54)\end{array}$

$\begin{array}{llll}-4.67 * * & -4.92 * * & -9.31 * * * & -2.92\end{array}$

(2.21) (2.18) (3.02)

$-1.91-2.90$

$-4.82 *$

$-0.19$

(2.50)

(2.08)

$-30.08^{* *}$

(12.79)

7.97**

(3.14)

$0.55^{\wedge}$

(0.87)

$4.98^{\wedge \wedge}$

(14.12)

$-3.15^{\wedge \wedge}$

(7.32)

$-0.82^{\wedge \wedge}$

(2.86)

$\begin{array}{cc}374.76 & 220.94 \\ 0.0000 & 0.0000 \\ 2006 & 2006\end{array}$

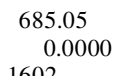

553.94
0.0000

418.56

0.0000

Notes:

${ }^{\text {a }}$ Per capita income is log of per capita GDP in \$ in 1985 constant prices. Source: Penn World Tables.

${ }^{\mathrm{b}}$ Trade openness is log of the sum of exports and imports over GDP. Source: Penn World Tables. 


\section{TABLE 1. continued}

${ }^{\mathrm{c}}$ Democratic institutions. Five-year average of democratic institutions. Variable goes from 1 (democracy in the previous 5 years) to 0 (non-democracy in the previous five years). Average calculated from data in Alvarez et al. 1996.

Estimation: Ordinary least squares estimation, with panel-corrected standard errors, and correction for autocorrelation and for heteroskedastic disturbances between panels.

Standard errors in parentheses.

$* * * p<.01$

$* * p<.05$

$* p<.10$

${ }^{\wedge}$ Joint test significant with separate components and interactive terms significant at .05 level.

$\wedge \wedge$ Joint test significant with separate components, interactive term and openness, significant at .05 level.

The estimates in Table 3 can be read as making direct predictions about how changes in openness and regime lead to changes in the size of the public sectorrather than giving equilibria values as in Tables 1 and 2 .

Column 1 in Table 1 reports the results of the estimation for the baseline model in previous studies on trade and the size of the public sector. It includes economic development, trade, and political regime. Economic development is measured as the log value of real per capita income (in constant dollars, Chain Index, expressed in international prices, base 1985), taken from the Penn World Tables. Trade corresponds to a measure of the impact of openness on governments, calculated as the log value of the ratio of trade (sum of imports and exports) to GDP, and is taken from the Penn World Tables. ${ }^{23}$ Political Institutions is a variable that indicates whether each country was a competitive democracy in the previous five years-and thus ranges from 0 (no democracy ever) to 1 (democracy in the five years). To measure the presence of a democratic regime, we follow the index developed by Alvarez, Cheibub, Limongi, and Przeworski and the classification reported in appendix 1 of their article. ${ }^{24}$ Democratic regimes are defined as those regimes "in which some governmental offices are filled as a consequence of contested elections."25

23. Openness rather than tariff (and nontariff) barriers are employed for two reasons. On the one hand, we are interested in measuring the potential effects that trade openness may have on the size of the public sector. Although tariffs are naturally employed to alter the extent of openness, there are cases where, although tariffs are low, the degree of exposure to the world business cycle is relatively low (for example, the United States due to the size of the country) and hence political pressure for domestic compensation is low. On the other hand, given the increasingly marginal role of tariffs, the direct measurement of trade policy instruments is substantially problematic. Still, as shown below, we have also attempted to separate the natural from the policy-induced levels of trade openness.

24. Alvarez et al. 1996.

25. Ibid., 4. We have also regressed the dependent variable on a variable that indicates whether each country was a 'bureaucracy' each year; a variable that indicates whether each country was an 'autocracy' each year; and a variable that indicates whether each country was independent each year. Bureaucracies are those dictatorships that have legislatures. Autocracies are those dictatorships that do not and that therefore can be thought of as not having any sort of institutionalized rule for operating the government. The presence of autocracies and bureaucracies is also based on the index developed by Alvarez et al. 1996. 
TABLE 2. The robustness of the effects of trade and political regime

\begin{tabular}{|c|c|c|c|c|c|}
\hline \multirow[b]{2}{*}{ Independent variables } & \multicolumn{5}{|c|}{ Public revenue as percent of GDP, 1950-1990 } \\
\hline & $\begin{array}{l}\text { Beck-Katz } \\
\text { lagged } \\
\text { revenue }\end{array}$ & $\begin{array}{l}\text { Fixed } \\
\text { effects no } \\
\text { lag } \\
\text { revenue }\end{array}$ & $\begin{array}{l}\text { Fixed } \\
\text { effects } \\
\text { lagged } \\
\text { revenue }\end{array}$ & $\begin{array}{l}G L S \\
\text { random no } \\
\text { lag } \\
\text { revenue }\end{array}$ & $\begin{array}{l}G L S \\
\text { random } \\
\text { lagged } \\
\text { revenue }\end{array}$ \\
\hline Constant & $\begin{array}{l}-2.20^{*} \\
(1.15)\end{array}$ & $\begin{array}{l}-65.78 * * * \\
(2.88)\end{array}$ & $\begin{array}{l}-7.49 * * * \\
(1.71)\end{array}$ & $\begin{array}{l}-58.90 * * * \\
(4.51)\end{array}$ & $\begin{array}{l}-5.06 * * * \\
(1.44)\end{array}$ \\
\hline Public revenue $t-1$ & $\begin{array}{l}0.94 * * * \\
(0.01)\end{array}$ & & $\begin{array}{l}0.89 * * * \\
(0.01)\end{array}$ & & $\begin{array}{l}0.92 * * * \\
(0.01)\end{array}$ \\
\hline Per capita income $(\log )^{\mathrm{a}}$ & $\begin{array}{l}0.33 * * \\
(0.16)\end{array}$ & $\begin{array}{l}11.77 * * * \\
(0.41)\end{array}$ & $\begin{array}{l}1.07 * * * \\
(0.25)\end{array}$ & $\begin{array}{l}11.32 * * * \\
(0.39)\end{array}$ & $\begin{array}{l}0.70^{* * * *} \\
(0.18)\end{array}$ \\
\hline $\begin{array}{l}\text { Trade openness (log of sum } \\
\text { of exports and imports } \\
\text { over GDP) }\end{array}$ & $\begin{array}{r}0.18^{\wedge} \\
(0.26)\end{array}$ & $\begin{array}{l}-1.49^{* *} \\
(0.60)\end{array}$ & $\begin{array}{r}0.43^{*} \\
(0.29)\end{array}$ & $\begin{array}{c}-0.91 \\
(0.57)\end{array}$ & $\begin{array}{r}0.27^{\wedge} \\
(0.22)\end{array}$ \\
\hline Democratic institutions $^{c}$ & $\begin{array}{c}-0.55^{\wedge} \\
(1.01)\end{array}$ & $\begin{array}{l}-21.48 * * * \\
(2.48)\end{array}$ & $\begin{array}{r}-1.34^{\wedge} \\
(1.25)\end{array}$ & $\begin{array}{l}-20.70 * * * \\
(2.41)\end{array}$ & $\begin{array}{c}-1.03^{\wedge} \\
(1.00)\end{array}$ \\
\hline $\begin{array}{l}\text { Democratic institutions } \times \\
\text { trade openness }\end{array}$ & $\begin{array}{c}0.27^{\wedge} \\
(0.26)\end{array}$ & $\begin{array}{l}6.35 * * * \\
(0.65)\end{array}$ & $\begin{array}{r}0.49^{\wedge} \\
(0.33)\end{array}$ & $\begin{array}{l}6.16^{* * *} \\
(0.63)\end{array}$ & $\begin{array}{c}0.40^{\wedge} \\
(0.26)\end{array}$ \\
\hline Log area (thousand $\mathrm{km}^{2}$ ) & $\begin{array}{c}0.08^{*} \\
(0.05)\end{array}$ & & & $\begin{array}{l}1.07 * * * \\
(0.35)\end{array}$ & $\begin{array}{l}0.14 * * \\
(0.06)\end{array}$ \\
\hline Distance & $\begin{array}{c}-0.06 \\
(0.04)\end{array}$ & & & $\begin{array}{l}-0.66^{* *} \\
(0.33)\end{array}$ & $\begin{array}{c}-0.06 \\
(0.05)\end{array}$ \\
\hline Subsaharan Africa & $\begin{array}{c}0.49 \\
(0.34)\end{array}$ & & & $\begin{array}{l}2.10 \\
(3.45)\end{array}$ & $\begin{array}{c}0.67 \\
(0.61)\end{array}$ \\
\hline East Asia & $\begin{array}{c}0.07 \\
(0.27)\end{array}$ & & & $\begin{array}{c}-2.32 \\
(3.28)\end{array}$ & $\begin{array}{c}0.13 \\
(0.57)\end{array}$ \\
\hline Latin America & $\begin{array}{c}-0.09 \\
(0.30)\end{array}$ & & & $\begin{array}{l}-9.69 * * * \\
(3.44)\end{array}$ & $\begin{array}{c}-0.25 \\
(0.61)\end{array}$ \\
\hline OECD countries & $\begin{array}{c}0.22 \\
(0.31)\end{array}$ & & & $\begin{array}{l}-10.68^{* * * *} \\
(3.20)\end{array}$ & $\begin{array}{c}0.07 \\
(0.59)\end{array}$ \\
\hline $\begin{array}{l}\text { Model Chi-square } \\
\mathrm{P}>\text { Chi-square }\end{array}$ & $\begin{array}{l}63562.2 \\
0.0000\end{array}$ & & & & \\
\hline $\mathrm{R}$-squared & & 0.587 & 0.968 & 0.665 & 0.971 \\
\hline Number of observations & 1493 & 1605 & 1494 & 1605 & 1494 \\
\hline
\end{tabular}

Notes:

${ }^{\mathrm{a}}$ Per capita income is log of per capita GDP in \$ in 1985 constant prices. Source: Penn World Tables.

${ }^{\mathrm{b}}$ Trade openness is $\log$ of the sum of exports and imports over GDP. Source: Penn World Tables.

${ }^{c}$ Democratic institutions. Five-year average of democratic institutions. Variable goes from 1 (democracy in previous 5 years) to 0 (non-democracy in the previous five years). Average calculated from data in Alvarez et al. 1996.

Estimation: Ordinary least squares estimation, with panel-corrected standard errors, and correction for autocorrelation and for heteroskedastic disturbances between panels.

Standard errors in parentheses.

$* * * p<.01$

$* * p<.05$

$* p<.10$

${ }^{\wedge}$ Joint test significant with separate components and interactive terms significant at .05 level. 
TABLE 3. The impact of changes in political regime and trade on rates of change of public revenue

Public revenue as percent of GDP, 1950-1990

Independent variables

(1)

(2)

Constant

$$
\begin{gathered}
0.04 * * * \\
(0.01) \\
-0.001 * * * \\
(0.000) \\
-0.02 \\
(0.51) \\
-0.64 \\
(0.73) \\
-1.16 \\
(0.72) \\
1.14 * \\
(0.71)
\end{gathered}
$$

Change in log of per capita income ${ }^{a}$

$0.06 * * *$

Change in political regime ${ }^{\mathrm{c}}$

Change in interaction of trade openness and political regime

$\begin{array}{cc} & -0.000 \\ & (0.000) \\ & -0.001 \\ & (0.002) \\ & 0.001 \\ & (0.033) \\ & -0.005 \\ & (0.013) \\ & -0.001 \\ & (0.018) \\ 43.90 & 0.009 \\ 0.0000 & (0.013) \\ 1267 & 49.84 \\ & 0.0000 \\ & 1050\end{array}$

Log area (thousand $\mathrm{km}^{2}$ )

(0.62)

$-0.54^{\wedge}$

$(0.76)$

$0.98^{\wedge}$

(0.74)

$-0.000$

Distance

Subsaharan Africa

East Asia

Latin America

OECD countries

49.84

Model Chi-Square

Prob $>$ Chi-Square

Number of observations

1267

1050

\section{Notes:}

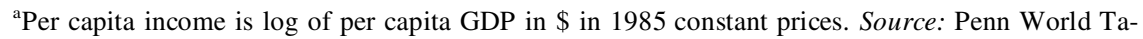
bles.

${ }^{\mathrm{b}}$ Trade openness is $\log$ of the sum of exports and imports over GDP. Source: Penn World Tables.

${ }^{c}$ Democratic institutions. Five-year average of democratic institutions. Variable goes from 1 (democracy in previous 5 years) to 0 (non-democracy in the previous five years). Average calculated from data in Alvarez et al. 1996.

Estimation: Ordinary least squares estimation, with panel-corrected standard errors, and correction for autocorrelation and for heteroskedastic disturbances between panels.

Standard errors in parentheses.

$* * * p<.01$

$* * p<.05$

${ }^{\wedge}$ In joint test of the interactive term and its separate components, statistically significant with Prob $>\chi^{2}=0.00$. 
Economic development and trade openness affect positively the size of government. Other things being equal, public revenue goes up from 20 percent of GDP for a real per capita income of $\$ 1,000$ to about 30 percent of GDP for a per capita income of $\$ 5,000$ and more than 40 percent of GDP for a per capita income of $\$ 25,000 .^{26}$ The results confirm a considerable literature relating the size of the public sector to economic development. ${ }^{27}$ For trade, in turn, public revenue goes up from around 23 percent of GDP in a closed economy (where exports and imports equal 10 percent of GDP) to almost 30 percent of GDP (if trade openness equals 50 percent of GDP) and up to almost 35 percent when openness is very high (around 150 percent of GDP). ${ }^{28}$ The results confirm the existing literature on the public sector as a compensatory mechanism in open economies. ${ }^{29}$ The presence of democratic institutions has a slightly positive effect on the size of revenue-it is 2.69 percent of GDP higher if the country is democratic.

To test for the model developed in sections 1 and 2, which showed that trade shapes the size of the public sector conditional on the political institutions in place, we add, to the basic model of Table 1, the interactive term "Democratic Institutions * Trade Openness" (Table 1, column 2). Per capita income and trade openness continue to boost public revenue. The presence of democratic institutions slightly reduces public expenditure. But this result has to be set against the positive sign of the interactive term. Given how strongly correlated it is to openness and democracy, it is not strange that the interactive term is only significant at the 16 percent level. Still, a joint test with openness and democracy shows that it is statistically significant (Prob $>\chi^{2}=0.0000$ ). In short, as trade grows, the public sector grows in democratic regimes. ${ }^{30}$

26. This is estimated by setting trade openness equal to 50 percent and assuming there is a democratic regime.

27. See Cutright 1965; Wilensky 1975; Hicks and Swank 1992; and Huber, Ragin, and Stephens 1993. Except for the weight of the primary sector and the dependency ratio, all other economic and demographic variables related to development-the urbanization rate, the percentage of the labor force in the primary sector and in the manufacturing sector, the percentage of agricultural land, and the proportion of the population below 15 and 25-are not statistically significant. Since trade is the variable under analysis in this article, we have only included per capita income in our regressions here. For a full analysis of the impact of economic modernization in all its dimensions on the size of the public sector, see Boix 2001.

28. This is estimated by setting per capita income equal to $\$ 4,000$ and assuming there is a democratic regime.

29. See Katzenstein 1985; and Rodrik 1998.

30. As discussed in note 16 above, the size of public compensation to losers may be related to their size and type. More specifically, compensation may be larger in labor-scarce economies than in labor-abundant ones since in the former a larger group (those deriving their income from wages) are hurt by trade. Although this article is focused on the impact of trade across regimes, we have tentatively examined the impact of labor abundance on the size of the public sector in two ways. First, we have added to the model reported in column 2 in Table 1 an interaction of per capita and trade openness under the assumption that richer nations have higher capital/labor ratios. Second, we have run a model with the $\log$ of capital stock per worker (as reported in the Penn World Tables), alone, in combination with trade openness and in interaction with openness and democracy. As expected, the size of the public sector grows with capital abundance (that is, with scarce labor and then a more pressing need to compensate). 
The benchmark regression of column 2 is robust to the introduction of geographical dummies, the log value of geographical area and the distance of each country from the major world exporters - this is done in column 3. The introduction of continental dummies, a standard procedure in economic studies, controls for specific effects of particular world regions. ${ }^{31}$ The inclusion of the log value of geographical area of each country and the distance to the twenty major exporters serves two purposes. First, the log of area controls for the possibility that the provision of public services is subject to economies of scale. Since area and trade openness are correlated, one could not exclude the possibility that the correlation between openness and public sector could be a spurious one due to other factors. However, as shown in column 3, the effect of trade openness is not affected by the introduction of area. As a matter of fact, the log of area positively enters the regression, disproving the economies of scale argument. Second, the $\log$ of area, jointly with distance, controls for the exogenous or structural component of trade openness. As shown by Frankel and Romer, distance, geographical area, and population explain a substantial portion of the share of exports and imports in each country's economy. ${ }^{32}$ Thus their inclusion in the regression as control variables allows us to measure the impact that trade openness, as a policy choice, has on the size of the public sector. ${ }^{33}$ Three results emerge from their introduction. First, the coefficient of trade openness declines in size (an unsurprising result given the impact of area and distance on the openness) but remains significant. More importantly, the interactive term of trade and political regime remains significant and has a slightly larger impact on the size of government. Finally, notice that size has a positive effect (rather than the negative effect we would expect from the idea that smaller, and hence more likely to be open, countries will spend more) and distance has a negative but not substantial effect (one standard deviation in distance changes public revenue by only 1.4 percentage points of GDP). In our opinion, these results mean that domestic compensation is mainly driven by political decisions (as captured by openness, net of the structural elements, and the interactive term) rather than by structural determinants (estimated through area and distance).

Figure 2 simulates the results of Table 1, column 3 . The simulation shows the evolution of current public revenue when trade openness goes up for a country of a per capita income equal to $\$ 4,000$. When trade openness is low, that is, when the sum of exports and imports amounts to 10 percent of GDP, public revenues are about 23 percent of GDP in both democratic and authoritarian regimes. As the economy opens, the size of the government increases at different rates. In author-

Our main results on trade and democracy remain unaffected by the inclusion of that variable. Results can be obtained from the authors.

31. See Rodrik 1998; and Barro 1997.

32. Frankel and Romer 1999.

33. The introduction of the variable "Population" in the regression does not change the results shown in the article. Since its coefficient is not statistically significant and the variable is tightly correlated to area, it has not been included in column 3 . 


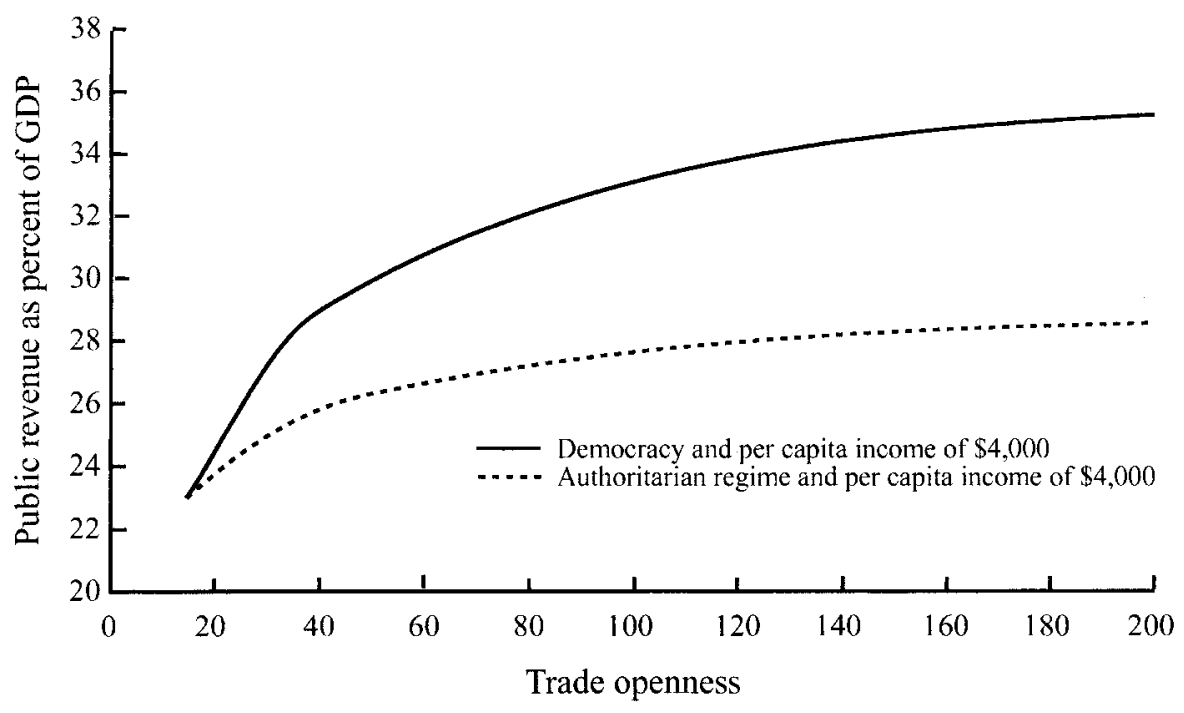

FIGURE 2. Public revenue as a function of trade openness and political regime

itarian regimes, it only goes up 5 percentage points to 28 percent (for exports and imports equal to 100 percent of GDP). In democratic regimes, instead, it goes up by 10 percentage points to reach 33 percent of GDP.

In short, trade openness partly pushes public revenue upward. But the combination of political regime and openness speeds up the formation of larger governments. In closed economies, politicians have few incentives to engage in substantial public spending. In open economies, a large public sector emerges as the price that the tradable part of the economy has to pay to ensure the acquiescence and cooperation of both the sheltered economy and declining tradable industries. Finally, no compensatory programs develop in those countries in which, although openness is maintained (to the benefit of the most powerful sectors in the economy-for example, plantation or mines' owners), political participation is restricted, and those sectors most hurt by economic openness are systematically excluded from government. $^{34}$

Columns 4 through 6 in Table 1 probe deeper into the mechanisms through which trade openness leads, in a democratic regime, to a larger public sector. Column 4 includes Lee's weighted level of tariffs on imports of intermediate inputs and capital goods. ${ }^{35}$ This measure, which ranges from 0.85 in India to 0.36 in Hong Kong, can

34. As already emphasized above, we do not claim that the choice of regime is exclusively determined by trade factors. We rather argue that, ceteris paribus, the alignment of trade interests contributes to the choice of a particular political regime.

35. Lee 1993. 
be thought of as a direct measure of the extent to which domestic policy imposes barriers to trade. The results strongly support our theory. The coefficients of both trade openness and its interaction with democracy remain stable and statistically significant. Moreover, as expected, an increase in tariffs is correlated with a reduction in the size of the public sector.

Columns 5 and 6 consider in turn two variables that may be thought of as mostly tapping the degree to which the domestic economy is affected by a higher risk of having to bear a volatile world business cycle as it opens its borders. ${ }^{36}$ Column 5 introduces an index of the product concentration of exports in each country, alone and in interaction with trade and democracy. This export concentration measure, which is a Gini-Hirschman index of concentration based on 239 three-digit standard international trade classification categories of exports as estimated by the United Nations Council on Trade and Development, varies from 0.06 (a highly diversified economy) to 1 (whenever only one product is exported). Openness and its interaction with political regime continue to perform strongly. The level of export concentration depresses public revenue significantly. ${ }^{37}$ The interactive variables of trade openness with export concentration and of these two measures and democracy have positive and statistically significant coefficients. As the tradable sector becomes less diversified and has a more central role in the domestic economy, the pressure for domestic compensation clearly goes up. Under democratic regimes, this pressure intensifies even more.

Column 6 introduces a more direct measure of risk using the variability of the terms of trade. Following Rodrik, we define $\pi$ as the natural logarithm of the price of exports relative to imports, that is, the terms of trade. ${ }^{38}$ Assuming that the log of the terms of trade follows a random walk, the unanticipated component of the income effects of a change in the terms of trade can be expressed (as a percent of GDP) as $1 / 2[(x+m) / y][d \pi-\alpha]$ where $x$ stands for the volume of exports, $m$ for the volume of imports, $y$ for GDP, and $\alpha$ for the trend growth rate in the terms of trade. To calculate the level of volatility of the economy, we calculate the standard deviation of the change in the terms of trade over the previous five years to each observation. An increase in volatility is positively correlated with an increase in the size of the public sector. The interaction of trade openness with the standard deviation of the log of the terms of trade and the interaction of these two terms with democratic institutions, which are also included in column 6, have negative coefficients - that is, they depress the role of government. ${ }^{39}$ The statistical significance of the three new variables is relatively weak: they are only statistically

36. Rodrik 1998.

37. Since export concentration is in part negatively related to democracy (the correlation between the two variables is -0.38 for the whole sample and -0.50 for the late $1980 \mathrm{~s}$ ), the negative result is likely to be proxying the lack of redistributive programs in authoritarian regimes. See Boix and Garicano 2001 for a discussion of the relationship between economic structure and democracy.

38. Rodrik 1998.

39. As a result of considerable colinearity, the introduction of these volatility measures causes the interactive term of trade and democracy to become not significant. 
significant in a joint test with the log of trade openness, and they do not become significant even after we drop openness and the interactive term of openness and democracy. In part, these results may be due to the difference of gathering complete and reliable data series on the terms of trade in developing countries. In our opinion, however, the subdued role of the terms-of-trade measure mainly points out that the strategy of domestic compensation emerges, above all, to compensate losing sectors rather than to smooth, as some sort of insurance mechanism, the short-term volatility of the business cycle.

In Table 2 we report several tests to check the robustness of our results. First we introduce the lagged value of the dependent variable "Size of Government." Both trade openness and the interactive term have a positive effect on public revenue and are statistically significant in a joint test. The long-run coefficient of the interactive term, at around 4 , is close to the estimates of Table $1 .{ }^{40}$ Columns 2 and 3 then report the results of estimating the benchmark model (with and without the lagged value of the dependent variable) using a fixed-effect model, to account for potential idiosyncratic effects for different countries. Finally, columns 4 and 5 report the results of estimating a random-effects model (again with and without the lagged value of the dependent variable) with a standard procedure of a "variance-component" generalized least squares (GLS) technique (to correct for the ways in which assumptions underlying ordinary least squares estimations are violated by crossnational panel data). ${ }^{41}$ In all cases, the model is extremely robust to different statistical procedures.

In Table 3 we examine the impact that a change in either the level of trade openness or the type of political institution has in the rate of growth of the public sector. The lagged value of public revenue and the change in trade openness restrain the expansion of the public sector. By contrast, and in line with our previous estimations, a positive change toward more trade openness in democratic regimes has a direct impact on the size of the state.

\section{Historical Evidence}

So far we have employed both analytical methods and econometric evidence to stress how tariffs and taxes are jointly selected by politicians, conditional on the political mechanisms (democratic or authoritarian) employed to aggregate preferences. To bolster our analysis, we now examine a set of historical cases taken from very different key periods and geographical areas. First, we describe how fiscal and trade laissez-faire policies imposed under a very restrictive suffrage system in the first half of the nineteenth century were gradually replaced by a national framework based on free trade and compensation policies (in the United Kingdom and

40. The long-run coefficient is calculated as $\alpha_{2} /\left(1-\alpha_{1}\right)$, where $\alpha_{1}$ is the coefficient of the lagged value of the dependent variable and $\alpha_{2}$ is the coefficient of the variable of interest (the interactive term).

41. See Hsiao 1986; and Hicks 1994. 
Scandinavia) and protectionism without compensatory policies (in Australasia) in the twentieth century. The historical evidence for these cases provides us with all the outcomes that may take place, so to speak, in the upper threshold of Figure 2-that is, under democracy. Second, we discuss how free trade, the development of the welfare state, and the choice of political regime interacted in those countries affected by authoritarianism and the so-called third wave of democratization, paying special attention to Southern European countries. This discussion sheds light on the set of cases in the lower band of Figure 2 and on the way in which shifts in the structure of the electorate are related to changes in the role of the state.

\section{From Laissez-Faire to Compensatory Policies in Democratizing Europe (1830-1950)}

The introduction of a laissez-faire trade regime in the first half of the nineteenth century in Britain and its gradual extension to continental Europe in the following decades was achieved without any simultaneous expansion of domestic mechanisms of compensation. Free trade was introduced with the support of commercial and urban interests in Britain and the backing of working class associations. ${ }^{42}$ But the triumph of Manchesterian liberalism (the quasi-welfare system structured by the Poor Laws was dismantled around that period) was equally related to the extremely restrictive nature of the franchise. Only one in eight men were entitled to vote after 1833 and about three out of ten after 1868. Moreover, the electoral system was extremely biased against both rural areas, which had borne most of the losses of the tariff reform of 1846, and the urban poor.

The stability of the Cobdenite regime was put into question, however, by two parallel developments at the turn of the century. On the one hand, after the electoral reform of 1884, which equalized the franchise conditions of the rural counties to those already in place for urban counties, the British electorate doubled to encompass between two-thirds and four-fifths of the adult male population. ${ }^{43}$ On the other hand, a fall in agricultural prices and, above all, the growth of German competition, unnerved British public opinion. Several anti-free trade episodes, such as an early resolution of the National Conservative Associations in 1887 in favor of 'fair trade,' the 'Made in Germany' panic of 1896, and the reimposition of sugar dues, the coal export duty, and the corn duty in the late 1890s and early 1900 s, were preludes to a new political realignment on trade policy. Chamberlain's proposals for tariff reform became hegemonic within the Conservative party by 1906 . In turn, among Liberals and Labour intellectuals, free trade and state interventionism rapidly mixed in what Howe has termed the 'New Liberal' synthesis. ${ }^{44}$ Following a spate of works

42. See Rogowski 1989; and Schonhardt-Bailey 1991.

43. The proportion of enfranchised adult men varies across authors depending on the age chosen to count men and assumptions about the weight of plural vote in rural counties. For relatively low estimates, see McKibbin, Matthew, and Kay 1990. For high estimates, see Blewett 1972.

44. Howe 1997. 
by Adam, Haldane, and the Webbs calling for increased public spending on education, the Liberal League pamphlets of 1902 already defended a much more aggressive stance of the state in the market to defend Britain's commitment to free trade. Although the Liberal party won in the 1906 landslide election under the banner of free trade, the economic downturn of 1907-08 and stagnant real wages resulted in a marked popular shift to Tariff Reform candidates in several byelections. ${ }^{45}$ The Liberal government, now headed by Asquith and with Lloyd George in the treasury, immediately responded by creating an old-age pension program in 1908; raising land taxes through the 'People's Budget' and introducing labor exchanges and trade boards the following year; establishing national insurance for sickness, invalidity, and unemployment in 1911; and passing the Miners' Minimum Wage Act of 1912. The combination of free trade and compensation embraced by the Liberal cabinet pushed Conservatives and moderate Liberals into the tariff reform camp. As the Duke of Northumberland, a former opponent of tariff reform, wrote to Stratchey in the autumn of 1909 in reaction to Lloyd George's fiscal plans, "protection cannot be worse than Socialism. . .And as. . Tariff Reform or Socialism are the only possible alternatives at this moment, I am quite prepared to swallow the former." ${ }^{46}$ The political debate that emerged at the turn of the twentieth century continued to structure the agenda of the interwar period. The Conservative party led the battle for imperial protection in the 1923 elections and was able, with the growing support of manufacturers and the City, to impose its solution in 1931. By contrast, Labour, which had succeeded the Liberals as the progressive alternative, almost unanimously defended free trade.$^{47}$ The fiasco of the 1930s policies and the victory of Labour in 1945 eventually brought Britain to the camp of open borders and sizable public intervention.

A similar evolution, with a much faster and radical commitment to the compensation strategy, took place in Scandinavia. As shown by Baldwin for Denmark and partly for Sweden, the basis of universalist compensatory policies were already in place at the turn of the century. ${ }^{48}$ As soon as the Liberal party, sustained by the Danish farming community, secured a strong majority in parliament, all-inclusive, non-contributory, tax-financed pensions were established in the 1890s. The type and size of pensions directly responded to the tradable character of farming sector. First, they were "one of the more successful measures tried" to attract labor needed by the farmers to keep being competitive "just as competition and falling prices fettered their ability to improve conditions and stem migration." ${ }^{49}$ Second, because Danish farming producers by nature are takers of international-prices, their costs (and benefits) were spread across the whole population. As has been well

45. Searle 1992.

46. Quoted in Blewett 1972, 79.

47. As late as 1931, 93 percent of Labour candidates supported free trade in their manifestos. Howe $1997,285$.

48. Baldwin 1990 .

49. Ibid., 75. 
documented in the literature, the strategy of openness in conjunction with compensatory mechanisms deepened in the 1930s and intensified again in the 1960s and 1970 s. $^{50}$

The formation of a free trade plus compensation regime in Northern Europe contrasts with the combination of protectionist schemes and a smaller welfare state adopted by both Australia and New Zealand. ${ }^{51}$ In response to depressed economic conditions in the late nineteenth century, Australian Labor agreed to support tariff reform in exchange for the legal recognition of a minimum wage for unskilled labor. Legal wage regulation, which was systematically sustained through a national system of compulsory arbitration in industrial disputes enshrined in the federal constitution, had the objective to secure, in the terms of the 1907 Harvester Judgment from the Court of Conciliation and Arbitration, a "fair and reasonable wage" to meet "the normal needs of an average employee regarded as a human being living in a civilized community." 52 Sustaining a wage threshold required uncoupling (parts of) the domestic economy from international markets. A restrictive immigration policy in favor of preserving a 'white Australia' to block the inflow of low-wage, non-white workers became the masthead of the federal Labour platform in 1905. Similarly, both Australia and New Zealand erected a strong tariff system to sustain prices in the domestic manufacturing industry in the 1920 s and 1930s with clear success. Whereas export prices fell by 40 percent between 1920 and 1935, real weekly wages of workers only decreased by 5 percent in the same period in New Zealand. The use of methods to shape the wage structure significantly lessened any social demands for a large welfare state. In 1949-50, Australia only spent 4.7 percent of its GDP on social security-compared with an average of 8.0 percent in 14 advanced industrial democracies. ${ }^{53}$ By 1975, tax revenue as a proportion of GDP was 7.5 percentage points below the OECD average in both Australia and New Zealand. Still, equality of conditions was well preserved in both countries. The Gini index for Australia and New Zealand has been consistently lower than the average OECD Gini index by about a whole standard deviation of the sample (or 5 points). ${ }^{54}$

50. See Cameron 1978; and Katzenstein 1985. A brief set of data will give a sense of the difference in public interventionism by level of openness. In the early 1970s and among OECD nations, public spending in education averaged 5.4 percent of GDP in open economies (exports equal to 40 percent or more of GDP) and 3.7 percent in closed countries; income maintenance programs were 12.9 percent of GDP and 8.6 percent of GDP, respectively; public fixed capital formation was 4.5 percent and 3.7 percent of GDP respectively; subsidies were 2.5 and 1.2 percent, respectively; and labor market policies amounted (in 1985) to 1 and 0.5 percent in each set of countries. OECD various years.

51. See Castles 1985 and 1989; and Mabbett 1995.

52. Quoted in Castles 1989, 34-35. The introduction of a protectionist regime also required buying off the support of farmers through a system of subsidies.

53. Castles 1985.

54. Our own estimations based on Deininger and Squire's data set. Deininger and Squire 1996. 


\section{Free Trade, Democracy, and Taxes in Southern Europe (1930-1980)}

As shown in our previous discussion of historical evidence for the advanced world, the maintenance of a democratic regime forces states to deal with the pressures that derive from the international economy-either to close borders or to compensate their electorates. We now examine how, under institutional conditions making possible the exclusion of key sectors of the population, policymakers can evade that political and economic dilemma. With that goal in mind, we focus on the trajectory of Southern Europe, and particularly Spain, since that area has shifted trade policy regimes and constitutional systems several times in the last century.

The Great Depression and the establishment of authoritarian regimes triggered the introduction of strong autarkic economic policies in Southern Europe in the 1930s and 1940s. They were only abandoned in Italy after military defeat in 1945 and in Portugal and Spain in the 1960s after almost two decades of economic stagnation. Consider the case of Spain. Following an economic stabilization plan in the late 1950 s, the peseta was made convertible, import quotas were progressively dismantled, and foreign capital was aggressively courted. Economic liberalization was followed by a rapid growth of the tradable sector. The sum of exports and imports as a percentage of GDP rose from about 10 percent in 1958 to 22 percent in 1962 and then to 34 percent in 1974. The inflow of foreign private long-term capital went from 15 million US dollars in 1958 to 435 million ten years later. The share of employment in the primary sector was cut in half, and real per capita income more than doubled in fifteen years. ${ }^{55}$ The maintenance of an authoritarian regime until 1975 'freed' the Spanish state from actively responding to the rapid dislocation caused by the process of economic liberalization. Tax revenues as a proportion of GDP fluctuated around 17 percent throughout the 1960s and then climbed slightly to about 23 percent in 1974-a level equal to about half of the tax effort of any other mid-size European country. Expenditure on social policies was half the European level. ${ }^{56}$ Expenditure in education averaged less than 2 percent in the 1960 s-about a third of the German and French level. Very similar policies were pursued in Portugal. Even with higher levels of trade openness (the sum of exports and imports as a percent of GDP was around 55 percent in the 1960s), public revenues stood below 20 per cent of GDP under Salazar's authoritarian rule. ${ }^{57}$ Authoritarianism operated in a very similar fashion in Latin America's Southern Cone in the 1970s and in East Asia: it reconciled trade and financial liberalization with subdued growth of the welfare state. ${ }^{58}$

The combination of economic liberalization and minimal compensatory policies broke down with the transition to democracy in the mid 1970s. The process of trade

\section{Donges 1971.}

56. Maravall 1995.

57. For an analysis of the Portuguese case, see Corkill 1999.

58. Again, our main theoretical claim is neither that authoritarianism leads to free trade nor that the introduction of the latter requires an authoritarian (insulated) state, but rather that authoritarianism enables states to impose laissez-faire strategies in both trade and fiscal policies. 
liberalization, which culminated in the integration with the European Union, was overwhelmingly supported by voters. ${ }^{59}$ Yet, in the context of a democratic system, it was now accompanied by generous compensatory policies. After 1975, Spanish public expenditure grew by over 1 percentage point of GDP per year in real terms to reach 49.6 percent of GDP in 1993. Although an important part of that growth was simply due to the explosion of political demands that followed the introduction of free elections, part of the expenditure was related to the new conditions imposed by the rapid internationalization of the Spanish economy. In response to adverse international conditions, the Spanish government first spent heavily on unemployment benefits and injected money into entire industrial sectors-subsidies and capital transfers rose to 5.6 percent of GDP by 1982. In the mid- and late 1980s, the public sector then shifted the content of public expenditure to support strong capital formation policies that could increase Spain's competitiveness. Whereas subsidies and capital transfers were cut substantially by almost 2 percent of GDP between 1982 and 1989, public fixed capital formation rose by 2.1 points of GDP up to 5.2 percent of GDP in 1991, general education expenditure went up to 4.7 percent of GDP in 1994, and active labor market policies reached over 1 percent of GDP. Some of these new programs were supported with European structural funds, themselves a result of an explicit deal in which the Spanish cabinet supported German and French plans to forge the European Union in exchange for substantial transfers to Spain's poorer regions. ${ }^{60}$ The expansion of the Spanish state was reinforced by the decision of the Spanish government to integrate the peseta in the European exchange rate system in June 1989. With its hands tied in the realm of macroeconomic management, the Spanish government tried to buy off support from voters and unions for new plans to make Spain competitive (mostly through wage moderation) with generous programs that raised public spending by 2 percentage points from 1988 to 1990 - that is, even before the economic downturn of 1991-93 pushed both the public deficit and public spending upward by another 4 points of GDP.

\section{Conclusion}

In exploring the consequences that the international economy has on the domestic political arena, a growing literature shows that higher levels of trade systematically lead to a larger public sector across both developed and developing nations. ${ }^{61}$ As openness increases, the state, mainly acting as a benevolent dictator or a welfare maximizer, adopts a salient role to minimize the risks of higher economic integration and to compensate declining economic sectors. Politics is, however, promi-

59. Over half of the Spanish population judged membership in EU to be a 'good thing' in the early 1980s. This level of support climbed to two-thirds by the late 1980s. By contrast, only 5 percent considered membership to be detrimental to Spanish interests. Alvarez-Miranda 1996.

60. Boix 1998, 105-29.

61. See Cameron 1978; and Rodrik 1998. 
nently absent in this approach. Disregarding the most recent research on the political sources of different tariff regimes, trade is taken as an exogenously-determined variable. ${ }^{62}$ Neglecting the literature on the redistributive consequences of public spending, the growth of the public sector is then regarded as a merely functional response to the requirements of trade. ${ }^{63}$

A more satisfactory understanding of the relationship between the international economy and domestic politics requires, by contrast, taking into account the set of economic and political trade-offs that simultaneously underlie the choice of trade and fiscal policies. As we have shown, once this is done countries may pursue three (stylized) alternative strategies:

1. National policymakers may keep the domestic economy closed. Due to high tariffs or simply to natural barriers to trade (such as geographical distance or the size of the country), closed economies escape the variability of world business cycles and demand lower levels of compensation than open economies. In short, ceteris paribus, economic insulation depresses the level of public expenditure. According to our empirical results, in closed economies, such as Argentina, India, Iran, Japan, Mexico, or the United States, public revenue as a proportion of GDP is at least 10 points lower than it should be, given their respective level of development.

2. Once free trade policies are embraced, and given that Keynesian demand management is hardly available to open economies, policymakers can only ensure high levels of social welfare (and therefore the support required to govern) by expanding the public sector to shore up declining economic sectors. ${ }^{64}$ As small European nations democratized at the turn of the twentieth century, pressure from tradable sectors to establish welfare systems grew steadily. But it was mostly in response to the economic shock of the 1930s that political elites used welfare and investment spending to structure a pro-free trade coalition in small European states. ${ }^{65}$ That solution contrasted with the decision to set up protectionist policies as a way of steadying relative prices at home without having to raise taxes and redistribute income through the public sector in Latin America (and in New Zealand and Australia to some extent) by that same period of time.

3. Since the combination of openness and compensation requires higher taxes, policymakers may consider favoring a third political strategy. Excluding in a systematic manner-that is, through authoritarian rule - those sectors that may lose from increasing economic integration, governments avoid increasing public spending. As shown in our empirical analysis, in free trade authoritarian regimes, such as the East Asian economies, the public sector is 10 percentage

62. Keohane and Milner 1996.

63. See Esping-Andersen 1990; and Holsey and Borcherding 1997.

64. On demand management in open economies, see Alt 1985.

65. This argument is parallel to and encompasses Garrett's analysis of the decision of social democratic parties to establish compensatory policies in open economies. Garrett 1998. 
points of GDP smaller than in a democratic system with similar levels of economic integration.

The issues and results raised in this article are relevant to contemporary debates on the political and economic consequences of trade (and financial) integration on, at least, two counts: the sustainability of the welfare state, and the changes that the international economy may induce on the number and system of states. Consider the first question. Broadly speaking, the current literature on the effects of economic openness can be divided into two camps. On the one hand, the most extended (and popular) approach sees the process of economic globalization as simply imposing increasing constraints on the ability of states to govern the economy. On the other hand, a set of scholars points to the striking correlation between openness and the size of the public sector, calling into question the former's conclusions: the fact that most open economies consistently espouse larger governments shows, in an unequivocal manner, that more trade does not require more fiscal discipline - and that the opposite may be true. We find that, once all the relevant variables are taken into consideration, both approaches can be reconciled. Besides the size of each economic sector, two factors are relevant to the choice of the political-economic regime: the variability of risks derived from trading with other nations; and, above all, the productivity of each economic sector (especially the pro-free trade sector) - that is, how much gain (or loss) each sector derives from free trade relative to autarky. If varying productivity levels affect the policy mix that is chosen, two conclusions are in order. First, more openness does not automatically constrain the spending capacity of states. This is particularly true whenever public expenditure is geared toward the production of public goods, such as infrastructures or human capital, that raise growth rates. ${ }^{66}$ Second, how sustainable a large public sector is over time depends on the competitive advantage of the exporting sectors that pay for it. If this competitive advantage erodes, the incentive to sustain a large government declinesand countries (the South American path of the 1930s and 1940s) start shifting toward either a protectionist system or an authoritarian free trade regime. That public compensation may run into limits seems to be forgotten by the literature on trade and government growth. By modeling a conditional relationship between trade and the public sector, we take account of that fact without destroying the strong empirical association between globalization and the welfare state.

The way in which fiscal policy and trade regimes are related suggests also that our model may be useful to shed light upon the causes that explain the evolution of the state system and any historical variation in the number of nations. In its most stylized terms, our model describes a policymaker interested in maximizing the welfare function of the median voter to win elections (or, more generally, stay in power). The policymaker's first choice consists in either establishing a relatively

66. The article employs an aggregate measure of the size of public sector and therefore does not address the causes (and consequences) of different types of public spending (capital investment versus public consumption). For a discussion of these questions, see Alesina and Rodrik 1991; and Boix 1998. 
closed economy-where smoothing the business cycle is possible - or opening the economy-where demand management is fraught with risks. But the many ways through which autarky may come about have been left unexplored. By assumption, we have equated autarky to raising domestic tariffs. Nonetheless, a closed economy can be achieved by the integration of previously separated countries. In the framework of our model, the process of European unification can be understood as an alternative (and a more cost-effective) response to globalization than expanding the welfare state in each European nation one step further. In short, the model we present may be taken as a starting point to explore why and how politicians shift the locus of sovereignty to govern the economy and maximize the welfare of voters.

\section{Appendix}

The choice of policy is the result of two steps. In the first, voters vote in elections. In the second, they may consider restricting (or not) the vote given the outcomes of a fully democratic system.

\section{The Electoral Game}

Consider first the electoral game. $C, O$, and $P$ (where $C \leq O \leq P<50$ percent of voters) can choose among two parties in national elections. Both parties, $\Sigma$ and $\Omega$, commit to their policy programs before voters vote. After the election, the world business cycle either expands or recedes. $\Omega$, the free trade party, may just promise no tariffs $\lambda=1$ or it may promise free trade jointly with an scheme to compensate the $P$ sector with $\alpha_{\mathrm{o}}$ in recession times. In turn, $\Sigma$, the protectionist party, favors high tariffs $\lambda=0 .{ }^{67}$ Even if it does not have to compensate for volatility, it may offer a transfer $\alpha_{c}$ to $P$ s to outmatch $\Omega$ 's offer.

For $\Omega$ to win, $O$ and $P$ will have to vote for it. At election day, $P$ voters only know their expected returns under free trade (with possible compensation promised by $\Omega$ ) and under autarky (with possible transfer promised by $\Sigma$ ). If $\Omega$ wins, $P$ 's expected utility is

$$
E U_{p}=\pi P_{g}+(1-\pi) P_{b}+(1-\pi) \alpha_{o}
$$

If $\Sigma$ wins, $P$ 's expected utility is

$$
E U_{p}=P_{c}+\alpha_{c}
$$

Accordingly, $P$ voters choose $\Omega$ whenever (1) is bigger than $\left(1^{\prime}\right)$ :

$$
\pi P_{g}+(1-\pi) P_{b}+(1-\pi) \alpha_{o}>P_{c}+\alpha_{c}
$$

67. A corner solution in $\lambda$ is ensured by the linearity of $P$ 's expected utility. If $P$ s were risk averse, a partial reduction of tariffs, that is $0>\lambda>1$, would be $\Omega$ 's best strategy under some parameters. 
Given both that $P$ chooses under uncertainty and that the expected gains from openness are lower than the gains from autarky (condition $3^{\prime}$ in the main text), $\Omega$ must always commit to a compensation $\alpha_{\mathrm{o}}$ to attract $P$. This compensation has to meet two criteria. First, it has to outmatch any spending package $\alpha_{\mathrm{c}}$ promised by $\Sigma$. Second, it should not alienate the $O$ voters-otherwise they would not vote for the free trade party.

Assuming that the package $\alpha_{c}$ is financed from taxes on $C$ voters, the cost for every $C$ of the spending package $\alpha_{c}$ promised by $\Sigma$ to each individual $P$ cannot be higher than the difference between what each $C$ gains under a protectionist regime $\left(C_{c}\right)$ and what it gains under free trade $\left(C_{o}\right)$. Otherwise, $C$ would not vote for $\Sigma$. That is,

$$
\alpha_{c}<\frac{C}{P}\left(C_{c}-C_{o}\right)
$$

Allowing $\Sigma$ to tax both $C$ and $O$ (and, similarly, letting $\Omega$ tax $O$ and $C$ ) to finance the compensation package $\alpha_{c}\left(\alpha_{o}\right)$ does not alter the solution of the game because each side will try to extract the maximum resources from their opponents and will be willing to accept a tax that leaves them marginally better off.

$O$ voters vote for $\Omega$ if the gains of an open economy are greater than the gains of a closed economy even allowing for the expected cost of the compensation they have to pay to each $\mathrm{P}$ voter in a recession:

$$
O_{c}<O_{o}-(1-\pi) \alpha_{o} \frac{P}{O}
$$

Solving for expression (4), for $O$ to vote for $\Omega$, the following inequality has to hold:

$$
\alpha_{o}<\frac{O}{P(1-\pi)}\left(O_{o}-O_{c}\right)
$$

Given the maximum $\alpha_{c}$ that $\Sigma$ can offer (3) and the compensation $\Omega$ can promise (4') and substituting in (2), $P$ will always vote for $\Omega$ whenever:

$$
\frac{O}{P}\left(O_{o}-O_{c}\right)>P_{c}-\pi P_{g}-(1-\pi) P_{b}+\frac{C}{P}\left(C_{c}-C_{o}\right)
$$

In short, the free trade party, $\Omega$, will be more likely to win, other things being equal, the larger the number of $O$ s, the larger the probability of a good cycle, the fewer the number of $C$ s, and the lower $P$ 's returns are under autarky. If the number of $P$ s increases, party $\Omega$ will be more likely to win the smaller the distance in $P$ 's utility under trade with respect to autarky. ${ }^{68}$

68. $P$ voters do not have an incentive to set up their own party. To set it up, the new party should promise more than $\Sigma$ or $\Omega$. If, for example, the $P$ party offered more than $\alpha_{\mathrm{o}}$, the amount $O$ voters are willing to accept, $O$ voters would be better off voting for $\Sigma$, and the $P$ party would never be able to command a majority of votes. 
Moreover, if $P$ voters are risk averse, $\Omega$ will stand more chances to win the lower the degree of risk aversion.

\section{Political Regime}

Suppose that $w$ is the minimum cost of repressing each member of those economic sectors that are permanently excluded from government. For the $O$ sector, the total cost of a dictatorship will be $(P+C) w$ (that is, the cost of repression multiplied by the number of $P$ s and $C \mathrm{~s})^{69}$ and $O$ 's minimum per capita expenditure to impose a dictatorship will be $([\mathrm{P}+\mathrm{C}] / O) w$. In turn, $C$ 's minimum per capita cost to establish a dictatorship will be $([\mathrm{P}+\mathrm{O}] / \mathrm{C}) w .^{70}$ Given the minimum per capita cost of authoritarianism, $O$ will impose a dictatorship if three conditions are met:

1. First, the costs of imposing a dictatorship do not eat away the gains from trade:

$$
O_{o}-O_{c}>\frac{(P+C)}{O} w
$$

Similarly, the maximum per capita cost $C s$ are willing to pay to impose a dictatorship have to be less than their net gains from protectionism:

$$
C_{C}-C_{o}>\frac{(P+O)}{C} w
$$

2. Second, $O$ 's resources for repression are larger than those of $C$ so that a pro-free trade dictatorship cannot be contested by the protectionist sector. Solving expressions (6) and (7) for $w$, this occurs whenever:

$$
\frac{O}{(P+C)}\left(O_{o}-O_{c}\right)>\frac{C}{(P+O)}\left(C_{c}-C_{o}\right)
$$

3. Finally, the cost of maintaining a dictatorship must be lower than the cost of compensating $P$. This condition includes two scenarios:

3a. On the one hand, the minimum compensation for $P$ may be too costly for $\Omega$ to promise it (condition 5 does not hold) and $\Sigma$ accordingly wins the election. Still, $O$ may be able to impose an uncontested dictatorship ( 8 holds). This happens whenever:

$$
P^{2}\left(P_{c}-\pi P_{g}-[1-\pi] P_{b}\right)>C^{2}\left(C_{c}-C_{o}\right)-O^{2}\left(O_{o}-O_{c}\right)
$$

69. If we considered that $P$ voters only have to be repressed in recession times, the expected cost of dictatorship would shrink to $([1-\pi] P+C) w$.

70. We assume that the introduction of a dictatorship requires that the economic sector is previously organized through a party. As a result, $P$ cannot consider imposing a dictatorship. 
Clearly, this is more likely to happen the larger the number of $P$ s and/or $O$ s and the lower number of $C$ s, as well as for the larger relative welfare loss of $P$ s in an open economy without compensation.

3 b. On the other hand, although $\Omega$ can commit itself to a compensation package (and thus win the election), a dictatorship is cheaper than paying a compensation package. This occurs when the per capita cost of repression is lower than the per capita cost of compensating:

$$
\frac{(P+C)}{O} w<\frac{P}{O}\left[P_{c}-\pi P_{g}-(1-\pi) P_{b}+\frac{C}{P}\left(C_{c}-C_{o}\right)\right]
$$

If the $C$ s were ready to spend more than $w$ per repressed individual, we should substitute that particular amount in the place of $w$ in (10):

$$
\frac{(P+C)}{O} \frac{C\left(C_{c}-C_{o}\right)}{(P+O)}<\frac{P}{O}\left[P_{c}-\pi P_{g}-(1-\pi) P_{b}+\frac{C}{P}\left(C_{c}-C_{o}\right)\right]
$$

To better understand how changes in the parameters affect the choices of each sector, let us look more closely at the solution. The following equation (rewritten from 5) shows the number of $C$ s required to make voters indifferent between the two parties, given the other parameters:

$$
C=O \frac{\left(O_{o}-O_{c}\right)}{\left(C_{c}-C_{o}\right)}-P \frac{\left[P_{c}-\pi P_{g}-(1-\pi) P_{b}\right]}{\left(C_{c}-C_{o}\right)}
$$

Similarly, from (8), the expression below shows the number $C$ s required to counter the threat of an $O$ 's dictatorship:

$$
C=\frac{P \pm \sqrt{P^{2}+4 O \frac{\left(O_{o}-O_{c}\right)}{\left(C_{c}-C_{o}\right)}(P+O)}}{2}
$$

Both (5') and ( $\left.8^{\prime}\right)$, jointly with (11) can be plotted in the $O-C$ axis to study their interaction. When $C$ s and $O$ s experience similar relative gains with their preferred trade policy, the $O$ s are more likely to (if, at all) open the economy through dictatorship than through a feasible democratic government by $\Omega$. In those cases $\Sigma$ can easily outmatch any compensation package offered by $\Omega$ and the free-traders can only resort to violence. From (5'), it is evident that $O$ s have to more than outnumber the $C$ s to win democratically. This equilibrium is reinforced by any increase in $P$ 's $e x$ ante predisposition toward autarky. In that case, while $\left(8^{\prime}\right)$ does not shift in the $O-C$ axis, the space under which $\Omega$ can win democratically shrinks.

However, as $O$ 's relative gains from trade $\left(O_{o}-O_{c}\right)$ increase, the space for democracy increases at a faster speed than that for dictatorship. Notice that the slope of $\left(5^{\prime}\right)$ increases linearly in $\left(O_{o}-O_{c}\right)$ whereas it does so only in squared terms in $\left(8^{\prime}\right)$. The relative cost of both regimes, given by (11), is not affected by this change. Eventually (5') and ( $\left.8^{\prime}\right)$ cross at increasingly lower values of $O$ meaning that, a larger space for a free trade democracy is both 
possible and financially sound. Since the transfers promised by protectionists are now relatively smaller, it is both feasible to outmatch them and cheaper only to compensate the $P$ s rather than repress a larger number of people. Again, this result hinges on the strength of $P$ 's predisposition toward autarky.

\section{References}

Alesina, Alberto, and Dani Rodrik. 1991. Distributive Politics and Economic Growth. NBER Working Paper Series 3668. Cambridge, Mass: National Bureau of Economic Research.

Alt, James E. 1985. Political Parties, World Demand, and Unemployment: Domestic and International Sources of Economic Activity. American Political Science Review 79 (4):1016-40.

Alt, James, Jeffry Frieden, Michael J. Gilligan, Dani Rodrik, and Ronald Rogowski. 1996. The Political Economy of International Trade: Enduring Puzzles and an Agenda for Inquiry. Comparative Political Studies 29 (6):689-717.

Alvarez, Mike, José Antonio Cheibub, Fernando Limongi, and Adam Przeworski. 1996. Classifying Political Regimes. Studies in Comparative International Development 31 (2):3-36.

Alvarez-Miranda, Berta. 1996. El sur de Europa y la adhesión a la Comunidad: los debates políticos. Madrid: Centro de Investigaciones Sociológicas-Siglo Veintiuno de España Editores.

Aukrust, Odd. 1977. Inflation in the Open Economy: A Norwegian Model. In Worldwide Inflation: Theory and Recent Practice, edited by Lawrence B. Krause and Walter S. Salant, 109-26. Washington, D.C.: Brookings Institution.

Baldwin, Peter. 1990. The Politics of Social Solidarity: Class Bases of the European Welfare State. New York: Cambridge University Press.

Barro, Robert. 1997. Determinants of Economic Growth: A Cross-Country Empirical Study. Cambridge, Mass.: MIT Press.

Bates, Robert H., Philip Brock, and Jill Tiefenthaler. 1991. Risk and Trade Regimes: Another Exploration. International Organization 45 (1):1-18.

Beck, Nathaniel, and Jonathan N. Katz. 1995. What to Do (and Not to Do) with Time-Series Cross-Section Data. American Political Science Review 89 (3):634-47.

Blewett, Neal. 1972. The Peers, the Parties, and the People: The British General Elections of 1910. Toronto: University of Toronto Press.

Boix, Carles. 1998. Political Parties, Growth, and Equality. Conservative and Social Democratic Economic Strategies in the World Economy. New York: Cambridge University Press.

2001. Democracy, Development, and the Public Sector. American Journal of Political Science 45 (1):1-17.

Boix, Carles, and Luis Garicano. 2001. Democracy, Inequality, and Country-Specific Wealth. Unpublished manuscript, University of Chicago.

Cameron, David R. 1978. The Expansion of the Public Economy: A Comparative Analysis. American Political Science Review 72 (4):1243-61.

Campillo, Marta, and Jeffrey A. Miron. 1997. Why Does Inflation Differ Across Countries? In Reducing Inflation: Motivation and Strategy, edited by Christina D. Romer and David H. Romer, chap. 9, 335-57. Chicago: University of Chicago Press.

Castles, Francis G. 1985. The Working Class and Welfare: Reflections on the Political Development of the Welfare State in Australia and New Zealand, 1890-1980. London: Allen and Unwin.

—_ 1989. Social Protection by Other Means: Australia's Strategy of Coping with External Vulnerability. In The Comparative History of Public Policy, edited by Francis G. Castles, chap. 2, 6-52. New York: Oxford University Press.

Corkill, David. 1999. The Development of the Portuguese Economy: A Case of Europeanization. New York: Routledge. 
Cutright, Phillips. 1965. Political Structure, Economic Development, and National Social Security Programs. American Journal of Sociology 70 (5):537-50.

Deininger, Klaus, and Lyn Squire. 1996. A New Data Set Measuring Income Inequality. World Bank Economic Review 10 (3):565-91.

Donges, Juergon B. 1971. From an Autarchic Toward a Cautiously Outward-Looking Industrialization

Policy: The Case of Spain. In The Economic Development of Spain since 1870, edited by Pablo Martín-Aceña and James Simpson, 350-89. Aldershot, U.K.: E. Elgar.

Esping-Andersen, Gösta. 1990. The Three Worlds of Welfare Capitalism. Cambridge: Polity Press.

Frankel, Jeffrey A., and David Romer. 1999. Does Trade Cause Growth? American Economic Review 89 (3):379-99.

Frieden, Jeffry A., and Ronald Rogowski. 1996. The Impact of the International Economy on National Policies: An Analytical Overview. In Internationalization and Domestic Politics, edited by Robert O. Keohane and Helen V. Milner, chap. 2. New York: Cambridge University Press.

Garrett, Geoffrey. 1998. Partisan Politics in the Global Economy. New York: Cambridge University Press.

Gourevitch, Peter A. 1986. Politics in Hard Times: Comparative Responses to International Economic Crises. Ithaca, N.Y.: Cornell University Press.

Hicks, Alexander M. 1994. Introduction to Pooling. In The Comparative Political Economy of the Welfare State, edited by Thomas Janoski and A. M. Hicks, 169-88. Cambridge: Cambridge University Press.

Hicks, Alexander M., and Dwane Swank. 1992. Politics, Institutions and Welfare Spending in Industrialized Democracies, 1960-82. American Political Science Review 86 (3):658-74.

Holsey, Cheryl M., and Thomas E. Borcherding. 1997. Why Does Government's Share of National Income Grow? An Assessment of the Recent Literature on the U.S. Experience. In Perspectives on Public Choice: A Handbook, edited by Dennis C. Mueller, 562-89. New York: Cambridge University Press.

Howe, Anthony. 1997. Free Trade and Liberal England, 1846-1946. New York: Oxford University Press.

Hsiao, Cheng. 1986. Analysis of Panel Data. Cambridge: Cambridge University Press.

Huber, Evelyn, Charles Ragin, and John D. Stephens. 1993. Social Democracy, Christian Democracy, Constitutional Structure, and the Welfare State. American Journal of Sociology 99 (3):711-49.

Katzenstein, Peter J. 1985. Small States in World Markets: Industrial Policy in Europe. Ithaca, N.Y.: Cornell University Press.

Keohane, Robert O. and Helen V. Milner, eds. 1996. Internationalization and Domestic Politics. Cambridge: Cambridge University Press.

Lee, Jong-Wha. 1993. International Trade, Distortions, and Long-Run Economic Growth. IMF Staff Papers. 40:299-328.

Lipset, Seymour M. 1959. Some Social Requisites of Democracy: Economic Development and Political Legitimacy. American Political Science Review 53 (1):69-105.

Mabbett, Deborah. 1995. Trade, Employment, and Welfare: A Comparative Study of Trade and Labour Market Policies in Sweden and New Zealand, 1880-1980. Oxford: Clarendon Press.

Maravall, José María. 1995. Los resultados de la democracia: un estudio del sur y el este de Europa. Madrid: Alianza Editorial.

Mayer, Wolfgang. 1984. Endogenous Tariff Formation. American Economic Review 74 (5):970-85.

McKibbin, Ross, Colin Matthew, and John Kay. 1990. The Franchise Factor in the Rise of the Labour Party. In The Ideologies of Class: Social Relations in Britain, edited by Ross McKibbin, 66-100. New York: Oxford University Press.

Meltzer, Allan H., and Scott F. Richard. 1981. A Rational Theory of the Size of Government. Journal of Political Economy 89 (5):914-27.

OECD. Various years. OECD National Accounts. Main Aggregates. 1960-89. Washington, D.C.: OECD. 
Przeworski, Adam, and Fernando Limongi. 1997. Modernization: Theories and Facts. World Politics 49 (2):155-83.

Rodrik, Dani. 1998. Why Do More Open Economies Have Bigger Governments? Journal of Political Economy 106 (5):997-1032.

Rogowski, Ronald. 1989. Commerce and Coalitions: How Trade Affects Domestic Political Alignments. Princeton, N.J.: Princeton University Press.

Romer, David. 1993. Openness and Inflation: Theory and Evidence. Quarterly Journal of Economics 108 (4):869-904.

Rueschemeyer, Dietrich, Evelyne Huber Stephens, and John D. Stephens. 1992. Capitalist Development and Democracy. Chicago: University of Chicago Press.

Schonhardt-Bailey, Cheryl. 1991. Lessons in Lobbying for Free Trade in 19th-Century Britain: To Concentrate or Not. American Political Science Review 85 (1):37-58.

Searle, Geoffrey R. 1992. The Liberal Party: Triumph and Disintegration, 1886-1929. New York: St. Martin's Press.

Summers, Robert, and Alan Heston. 1988. A New Set of International Comparisons of Real Product and Price Levels: Estimates for 130 Countries, 1950-1985. Review of Income and Wealth 34 (1):1-26. United Nations. Various years. National Accounts. New York: United Nations.

Wilensky, Harold L. 1975. The Welfare State and Equality. Berkeley: University of California Press. World Bank. Various years. World Development Report. New York: Oxford University Press. 